DOI: $10.15503 /$ jecs20142.169.179

Journal of Education Culture and Society No. 2_2014

\title{
THE LANGUAGE OF FASHION AS A CARRIER OF PERSONAL INFORMATION
}

\author{
MARTA KOSOWSKA-ŚLUSARCZYK \\ Jesuit University Ignatianum in Kraków, \\ ul. Mikołaja Kopernika 26,31-501 Kraków, Poland \\ E-mail address: kosowska_marta@interia.pl
}

"Of all the numerous functions of dress, communicating the message comes to the foreground. The outfit is simply a visual message identifying its wearer through an established code" (Żygulski, 1994, p. 9).

\begin{abstract}
It's fair to say that all human life is based on communication; passive and active, verbal and nonverbal. No matter which media type you consider, the importance of the so-called first impression cannot be overstated. Currently, as the world becomes more open and accessible, the individual character of the way we create our look takes a different form, but still remains an important messenger. In my thesis, I would like to present the outfit as a carrier of vital information about people. In parallel, I will analyze the clothing itself, researching both historic and contemporary sources. Finally, I attempt to decipher the language of fashion.

Keywords: fashion, outfit, communication, language
\end{abstract}

\section{INTRODUCTION}

Fashion as a social phenomenon significantly affects the way we form our opinions about others. The birth of clothing derives from culture itself; only with clothing was culture created. The person came to be a part of the external appearance - "[...] he lived in his clothes, as if in himself" (Kuczyńska, 1983, p. 94). Clothing says a lot about people, human nature, a person's mood on a particular day, their social status, and profession. It is also one of the crucial elements of the first impression. My interest in fashion developed, when I entered the environment of so called fashionists - young designers and models drawn in by fashion trends, for whom the creation of an external-self is a priority. 
Historically, dress has always had a very symbolic meaning; communicating the differences between social classes and their roles. Today, as the result of common access to information and mass media, clothing has become an important aesthetic element firmly and strictly tied into mass culture. As a result, the way a person is dressed, often in a profound way indicates identity. Dress can also be a disguise that hides the person's true face.

The premise of my work revolves around the claim that the human "[...] has and uses - outside the proper body - the second body; namely what he wears on himself. Perhaps this «second body» allows him to express more than is in the essence of expression" (Kuczyńska, 1983, p. 12).

Current evidence suggests that if you want to succeed - you must follow a certain sets of rules and dress codes. Suitable colors, accessories and fashion elements are the key to success. Every industry has its own standards. Contemporary fashion is constantly creating new options - no age and gender is left out, the dress elements are interwoven with various styles and trends.

In her book from the late 70s, Teresa Kuczyńska rightly notes that "Today - everything is trendy and really - nothing is fashionable. Everything is permitted, except that which is prohibited and most fashionable. One could multiply such showy finding, because this today is illogical, inconsistent and often not aesthetic. And all this at the same time great" (Kuczyńska, 1977, p. 12). A culture can talk about the importance of the symbolism of the outfit. Formerly the essence of good manners was defined by one's ability to select appropriate clothing to the circumstances - going to church or work was associated with a different external appearances. Today, there is a noticeable blurring of boundaries and distinctions in matching outfit, inter alia, universities and schools, where the old standards are difficult to achieve, where pupils and students are moving away from the principles of color and neatness of dress. The outfit enters the space of the so-called anti-fashion, which stands in opposition to standards, which were shaped over the years. It is noticed, that in the contemporary culture, the way people dress and wear make-up is a sign of a certain social prestige (Rejakowa, 2010). That prestige seems to be the main goal and benchmark of modern world.

\section{THE NONVERBAL LANGUAGE OF FASHION}

"Fashion is really an universal principle which shapes a culture - it embraces and transforms not only the whole body but also all forms of human expression" (König, 1979, p. 30).

The way we communicate through our clothes is determined by the history of our approach towards clothes. In ancient times, clothes served as a distinction factor in society - the position of the Romans was signaled by the various togas (Illustration 1) and was intended only for Roman citizens. For example, the red toga embroidered with gold thread - the so-called toga picta - was meant to be worn exclusively by Cesar and consuls during the period of the triumphs (Outfits of the ancient Romans, n.d.). Informative function of one's dress plays a very important role in building social relations. It is undeniable that "all forms of dress communicate messages about the person who wears them - some are intentional, others are not" (Fisher-Mirkin, 1999, p. 14). Nowa- 
days, appropriate clothing can be a true ally during interviews, meetings, or at work - either helping you to achieve the intended goal, or to build positive social relationships. Choosing the right outfit according to the circumstances is one of the key elements of savoir vivre, indicating knowledge of specific principles and regulations. It is also a way of personal expression and a means to stand out in the surrounding world.
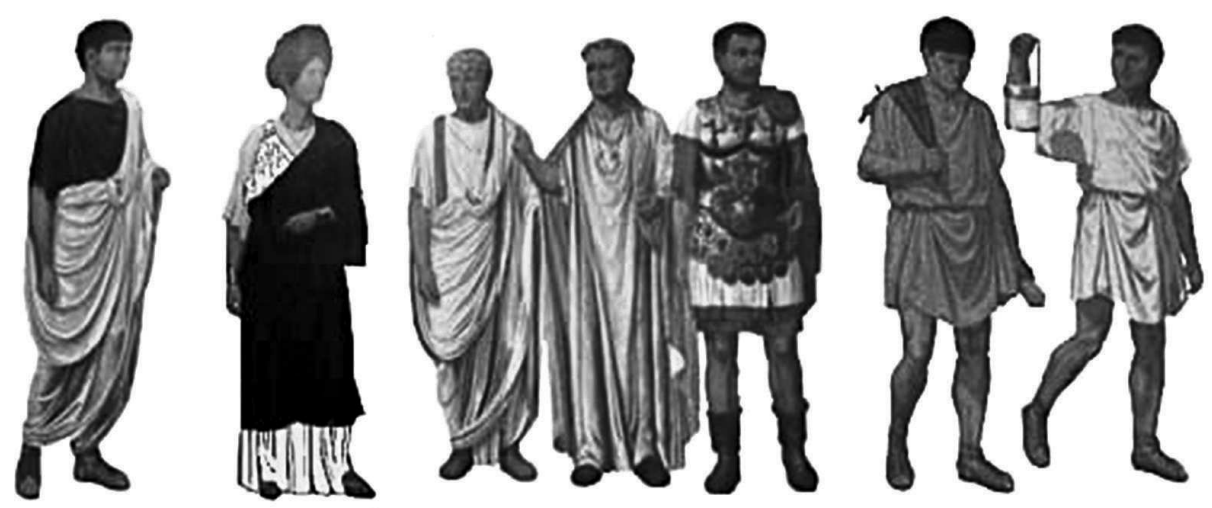

Illustration 1. Clothing of different society classes in the Ancient Rome

Source: Społeczeństwo rzymskie [Society of Rome]

http://www.imperiumromanum.edu.pl/spoleczenstwo_rzymskie.html

People have specific competencies, which enable them to use various forms of communication, both - verbal and nonverbal. Communication competencies cover a range of abilities and skills that a person acquires over time. It is important that "the primary purpose of communication is striving to achieve something specific. [...] Communication - apart from its adaptive qualities is also very liberating. There must be a relationship between all elements of the system in which the communication occurs" (Bochnia \& Bochnia, 2010, p. 66). Most of the messages sent by people are nonverbal. Activities and different attitudes that a person takes in certain situations, evidence of its intentions etc. require more than just the spoken language which is often insufficient (Bochnia \& Bochnia, 2010). Communication not only covers the verbal aspects, but also non-linguistic competences. The definition of communicative competence by Dell Hymes "[...] includes the unit's ability to select the linguistic and non-linguistic means, and takes into account the situation of speaking, which consists of cognitive and emotional characteristics of the sender, the role played by the social system of norms and values" (Sufa, 2008 , p. 13). Non-linguistic elements can include the external appearance of the man, including his clothing, which is also a very clear message to the audience. Non-verbal communication in the narrow sense "is relative to the part and the whole human body; it is a message in which using only static and dynamic properties of the human body will achieve the goal of communication between two or more people (Harrison, 1992; Hall 1978 Jarząbek 1989)" (Sufa, 2008, p. 15). It is worth noting that the first element, which becomes a gateway to establish social relationships, is the appearance and the external image of a man. Visibility and types of clothing can tell a lot about a person, his social status, membership in specific groups and institutions, performed profession, etc. "Non-verbal signals are more reliable and convincing and serve to: providing information, regulating interaction, expressing emotions, creating meta-communication, 
and shaping impressions" (Bochnia, \& Bochnia, 2010, p. 65). It can therefore be said that dress is one of the elements of non-verbal communication, which carries a lot of information about a person. "Physical appearance says everything about the person, including physical attractiveness, race, gender, height, build, clothing, and even smell. [...] When you assign different characteristics to other people, and succumb to the tendencies of perception and therefore the formation of impressions, you make mistakes" (Morreale, Spitzeberg, \& Barge, 2007, p. 180). This is how the way we dress often has a significant impact on other people's impressions about us. Numerous studies (Molloy 1988, Rasicot 1986, Smith and Malandro 1985) indicate that dress is a determinant of the four dimensions of the image:

- reliability;

- excitation of sympathy;

- interpersonal attractiveness;

- dominance (Leathers, 2007).

Paying special attention to these dimensions, can lead to the conclusion that the way we dress affects our further interpersonal relations. Currently, there are a certain number of guidebooks on how to dress to achieve success or find your dream job. These items indicate that certain style of clothing is the key to success, however, people must follow a fixed set of rules in order to achieve it (Rock, 2008), and that the key to finding your style is to define the silhouette and the body type and chose the contents of one's wardrobe accordingly. Kim Johnson Gross and Jeff Stone, in their book Kobieta sukcesu. Jak dobrać garderobę, by zdobyć i utrzymać posade [org. Dress Smart Women] indicate that appropriate attire is an important element to get a good job - "Your dress should clearly indicate that you fully deserve the current position and/or you're ready to make the next step. To make sure that this message gets to your surroundings, try to ensure that your clothes like your actions - are simple, consistent, elegant and well thought out" (Gross \& Stone, 2005 , p. 117). The authors point out the importance of dress code in communication. How we will be perceived by the environment depends largely on our external apparition.

On the other hand, the clothes we wear may also be associated with the transmission of other values, such as rebellion against the applicable standards and behavior enforced by certain institutions such as schools, because "our clothes and items that we use, provide information about our status, condition in life, and even our beliefs and values. [...] Clothing also allows you to communicate or to determine membership in specific social groups or cultures. Many big-city gangs are identified by what their members wear" (Morreale, Spitzeberg, \& Barge, 2007, p. 181) (Illustration 2). People often use clothing to hide some of the imperfections in their appearance and strengthen their self-esteem. Public opinion significantly affects the clothes choices, resulting in a departure from accepted standards associated with ridicule or rejection. "The physical attractiveness is strongly influenced by the ability to select socially appropriate clothes" (Leathers, 2007, p. 182) which are accepted by the people around us. Outfit is particularly dependent on the culture and religion in which a person was raised - these factors also affect our perception of certain parts of our bodies, which must be hidden under clothing. In many cultures of the African peoples bare breasts are a natural part of the external appearance of a woman and do not cause negative feedback which is contrary to the Western standards, where exposed breasts are even a subject of media censorship (Illustration 3). The opposite example is the clothing of Arab women - burqa, hijab or niqab (Clothing of Arab women, n.d.) 


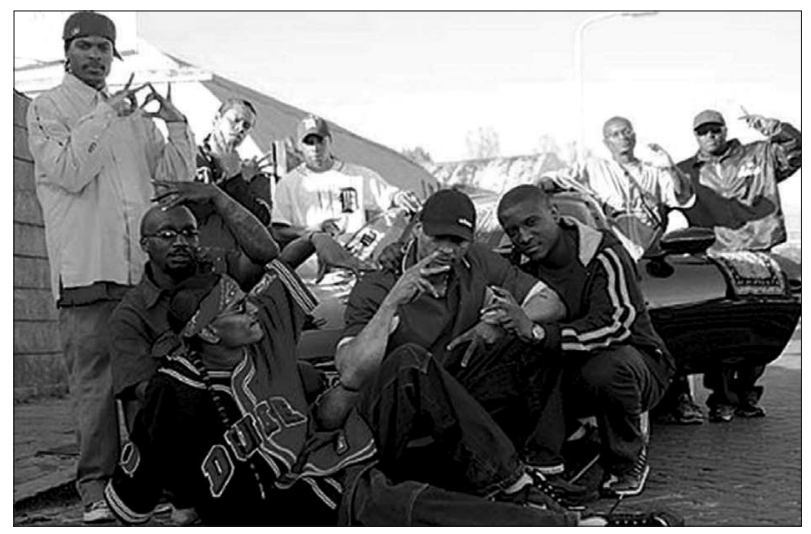

\section{Illustration 2.}

Crips gang members from Los Angeles wore blue for many years in order to indentify their collegues.

Source: Mafie i gangi świata: crips z Los Angeles [Mafias and gangs of the world: crips from Los Angeles],

http:/ / nasygnale.pl/gid,13534447,img,13 534872,title,Mafie-i-gangi-swiata-crips-zLos-Angeles, galeria.html

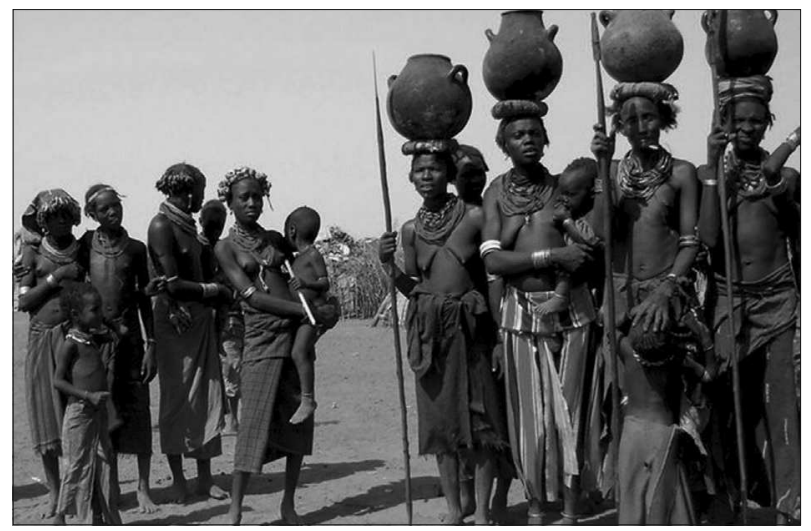

Illustration 3.

Women from Ethiopia

Source: Photo by Teresa Stachowicz.

Retrievedfrom Oblicza Etiopii -spotkanie w ExIF STuDIO [Faces of Ethiopiameeting in the ExIF STuDIO],

http://www.wiadomosci24.pl/artykul/ oblicza_etiopii_spotkanie_w_exif_ studio_168929.html

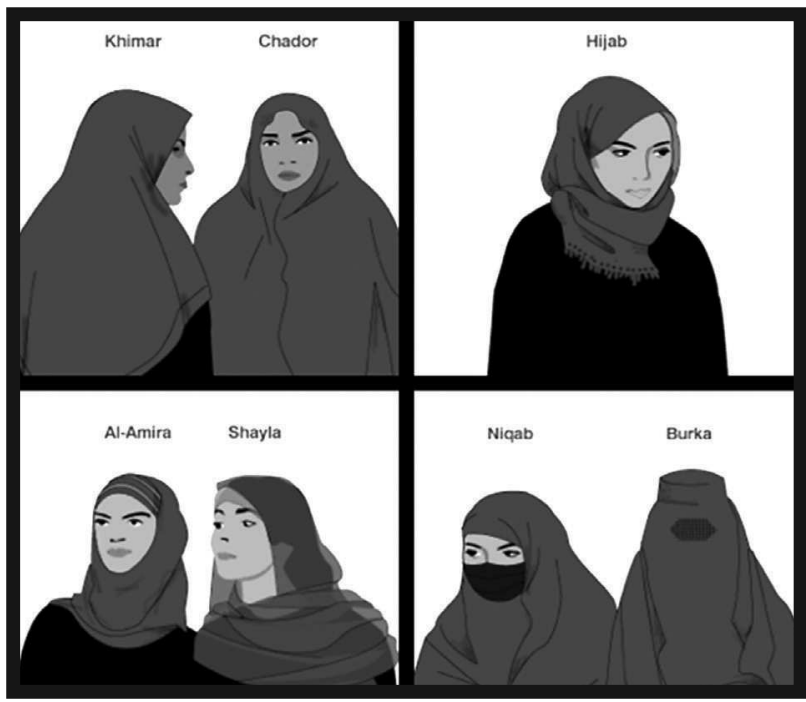

\section{Illustration 4.}

Muslim women

Source: Muslim women of Reddit, what are your opinions on the hijab/niqab/ burka and other forms of modest dress?, http://asset-3.soup.io/ asset/2016/6718_3d3e.png) 
- which almost completely hides the women's body, clearly communicating its religious affiliation (Illustration 4). Clothing - when considered anthropologically and socially contributes to the increased identification with a specific group.

\section{THE PAleTte OF COLORS AND MOODS}

"Color is probably the strongest element in the overall pronunciation of our outfit. After a few seconds, people respond to «a colorful message» sent by the way you dress" (Fisher-Mirkin, 1999, p. 25).

The color of objects around us as well as people and nature lies in the foreground of our perception of reality. Colors of our surroundings are the essence of a proper and convenient living environment. They are also closely connected with the culture of the given time, as each period in history has its selected palette of colors. Currently, the color red is associated with love, aggression, threats, while in the numerous countries of Asia, it is the color of wedding dresses. Additionally, in the medieval culture, wearing a red robe was reserved only for kings and aristocracy (Fisher-Mirkin, 1999). Similar differences emerge in the case of mourning garments. In the Euro-American cultures the color black is associated with death, while in some of the Asian countries white takes over (Colors of mourning, 2013). Currently, the choice of clothing color is optional and depends entirely on one's individual preferences. With each new season, new colors and styles are introduced, ultimately defining which color of clothes will be the most popular on the shopping shelves. Currently the color of clothes does not send such a clear message, as in the past. However, the individual selection does say a lot about the wearer's current state of mind and mood. Picking muted and inconspicuous colors may for instance be a symptom of one's desire to blend with the crowd, while accented tones and extravagant clothing may signal the opposite. The choice of color also says a lot about our personality and our relation to a specific color scheme, which is reflected in culture and religion.

Choosing the right outfit, is dictated by many external and internal needs, which guide our choice - in particular, the person's mood on the given day. It is noticed that darker clothes are more likely to be chosen by people who do not want to stand out from the crowd, or prefer to hide their emotions. Research carried out by the University of Hertfordshire shows that the outfit is strongly associated with mood. It points out for instance that most people wear jeans when they feel depressed - „One hundred women were asked what they wore when feeling depressed and more than half of them said jeans. Only a third would wear jeans when feeling happy. In a low mood a woman is also much more likely to wear a baggy top; $57 \%$ of the women said they would wear a baggy top when depressed, yet a mere $2 \%$ would wear one when feeling happy. Women also revealed they would be ten times more likely to put on a favorite dress when happy (62\%) than when depressed $(6 \%)^{\prime \prime}$ (Happiness: it's not in the jeans, 2012). Accordingly, what we wear during the day is not only dictated by our style of clothing, but also spiritual and mental condition. Dress becomes a message to the public: I have in a bad or good mood, I'm tired or happy and rested.

Dress is the determinant of our sexuality and eroticism - it has the potential to emphasize the physical qualities or hide them. Short skirt, high neckline, unbuttoned shirt and many others send out very clear messages to the opposite sex. However, the line between subtle and excessive provocation is thin, and the sign might be misunderstood. Often this error appears due to differences between one's self image and the way we are perceived by the outside world. In this case, the golden rule of communication - moderation - proves to be extremely important. 


\section{IN THE FASHION SNARE}

"When fashion lasts a long time, it ceases to be fashion and-unless it is transformed into its opposite - it becomes at best a part of a carelessly observed reality"

(Kuczyńska, 1983, p. 11).

Fashion is a dynamic phenomenon, which brings new and dynamically changing trends to human consciousness. Currently, fashion marks new directions by defining what is up to date and what becomes obsolete. Dynamism of this process stems from human need for constant change and the desire to find novelties.

In this context, fashion provokes a sense of ambivalence between what is socially acceptable, generally accepted as the norm, and the desire to stand out from the crowd. Ignorance and a lack of distance to the outer envelope of a man, as well as the pursuit of perfection often cause confusion and seizure of a person's consciousness. In the case of ambivalence one must face both positive and negative feelings that evoke the sense of being lost. The ability to deal with conflicting situations is acquired in the course of social interaction, but "[...] we will always have to deal with the pressures of a society that guards our behavior" (Kuczyńska, 1983, p. 18). That is why public opinion shapes the choices of individuals. Advertising appearing in the media influences the human taste and determines the choices taken. Unfortunately, excessive flow and access to information on a wide scale causes chaos due to the amount of content and weakening of the individual " $\mathrm{I}$ ".

The most exposed and vulnerable to the impact of the media is the younger generation who have not yet developed the skills to interpret and segregate information provided by the media. Furthermore, fashion itself is a phenomenon involving the whole person, not just the external appearance - it is a reflection of one's internal feelings and needs, as the human body is one of the primary means of expression. What is more "[...] fashion is a universal principle that shapes the culture; able to embrace and transform not only the whole body, but all forms of human expression" (König, 1979, p. 30). Actual fashion which usually appears in the media, unfortunately does not help to develop the appropriate gusto - short skirts and shorts, defiant, brilliant colors, transparency, etc. It becomes difficult for teens to escape the temptations of the contemporary fashion, which touches them at every step of their life. This leads to a paradox, which "[...] involves one's own individual image, while group membership «professes» a particular fashion" (König, 1979, p. 28).

\section{THE LANGUAGE OF FASHION}

"The language of fashion - in contrast to the language of linguistics - operates on the signs that have just a substitute material, but more importantly, create a unity with it"

(Kuczyńska, 1983, p. 11).

The language of fashion requires individual interpretation and perceptiveness of the receiver. It is not always specifically aimed, often reaching a wider group of recipients, for example during a walk through the crowded streets of the city. In the social context we acknowledge a certain catalog of dress symbolism, in which certain outfits 
are assigned to specific situations, people, operations or professions (such as a white dress for a bride, a white apron for a health service professional, police uniform, black veiling on the head, and many other examples (Kuczyńska, 1983).

Expressing the own " $\mathrm{I}$ " through clothing is one of the main prerequisites of modern fashion (Illustration 5). Today the fashion shows affect not only the shape of visual outfits, but most of all streets set the trends. The prestigious gadgets, such as expensive furs and cars are no longer the determinants of social status. Today, the famous people or movie stars present themselves more often in jeans and t-shirts than through the seasoned creations, which are currently used only for official events.

The problem of the social status determined by the dress slowly decreases as it was noticed at the end of the 70s, but I personally cannot quite agree with the fact that "[...] outfit ceased to be a distinguishing feature of social life. [...] However, it does not say that much about the financial position or social provenience" (Kuczyńska, 1977, p. 7). Nowadays, this problem is especially noticeable in schools, where brand clothing is often more important than its form. Clothes made by particular companies continue define one's prestige and social status. Increased discussion about school dress code originates from the desire to introduce the school uniform, which as indicated by the ministry of education, were supposed to blur the differences among students and reduce social rejection. According to research on the impact of standardized school attire on the identification with the school, the school uniform is associated with prestigious and private educational institutions (Kosowska, 2012). The school becomes a catwalk for the newly released, latest trends in fashion, where the student's position is determined by clothing and knowledge of the news from the world of fashion. Therefore, it can be argued whether uniforms are a suitable answer to the problem.

"Clothes also communicate someone's level of power or helplessness. This is especially true for people in uniforms. [...] Generally, we tend to assign people in uniforms bearing more desirable personal qualities" (Leathers, 2007, p. 185).

The uniforms not only affect the level of students' identification with the school, but also have a significant impact on their self-esteem (Illustration 6). It seems that the school uniform's resemblance to a military or police uniform has no particular effect. It is the appearance imposed by the institution that affects how others perceive people. Uniform or standardized dress (certain professions such as healthcare), sends a clear message about the wearer - who he/she is and what he/she does. It also inspires awe in the transferee.

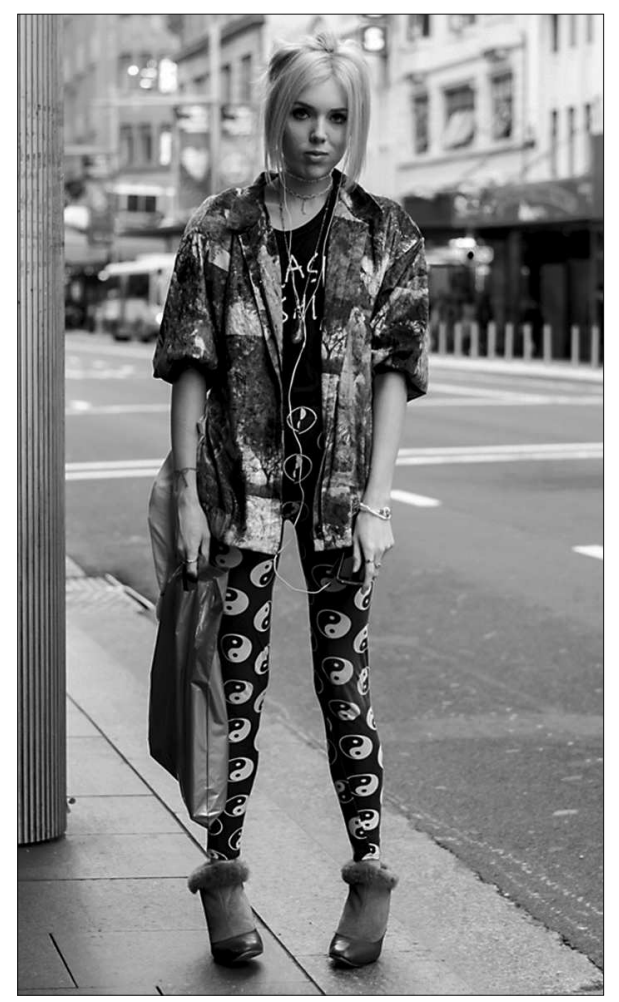

Illustration 5. Street style

Source: https:/ / keishikibi.com/street-styleher-0089/ 
Another aspect of the emerging issues related to the outfit, is the fact that the freedom to express yourself through dress is a human right and should not be limited. This right was acknowledged by the U.S. Supreme Court in 1969, which confirmed that the students have the right to self-expression through their appearance (Tinker v. Des Moines Independent Community School District, 1969). In the era of struggle for human rights, I believe that it is extremely important to consider the individual character of each person, and their appearance, because through such identification we find our place in the community.

An outfit can also become a trap that allows the hiding of your real face or doing the opposite by revealing one's inner self. Clothing can be a kind of mask that hides people's weaknesses or disingenuous intentions. Artificially created style can lead to disharmony also on the mental level. Sent messages are not consistent with personal feelings, which can cause confusion and even rejection, because "the suit is a part of the human interior, and represents him, but the human is an element of clothes that he represents" (Tarczyński, 2006, p. 27). Dishonesty in clothing is easily recognized. Expressing oneself through dress is now one of the fundamental tasks of clothing, which should send clear messages to the public, answering the publicly asked question - who am I. Due to the fall of the authorities and media pressures, young people reveal themselves through their wardrobe in order to highlight their individuality. Agnieszka Gawlik in her article Wyrabianie wrażliwości estetycznej, prowadzenia notatek, estetyka miejsca, estetyka ubioru [Manufacturing aesthetic sensitivity, keeping notes, aesthetics of places, aesthetics of the dress] characterized by successive age ranges its approach to children and youth apparel. The article points out that in the gymnasium - "The student's outfit is usually still dependent on their parents, though it happens that parents allow gymnasium students pick the school outfit" (Gawlik, 2002, p. 199). However, it is difficult to agree with this view, observing the appearance and behavior of adolescents in gymnasia, which gives the impression that they are out of control. This phenomenon is has been clearly observable over the past years, especially since the late '60's when young people were largely becoming members of various subcultures. "Through the clothing, or rather through the uniforms, a young person was recognized not only by the given subculture companions, but also potential enemies" (Hoffman, 2007, p. 29). Provocative outfits, often express the affiliation to subcultures or strongly emphasize the independence and freedom from the clutches of rules imposed by adults.

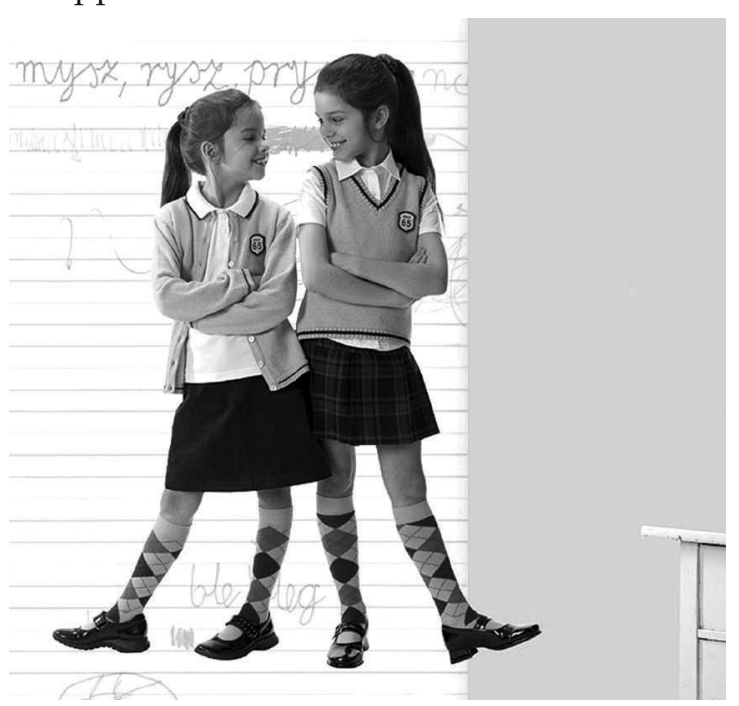

Illustration 6. School uniforms

Source: http://www.galla.pl/mundurki/00.jpg 


\section{CONCLUSION}

Fashion perfectly combines the problems of many disciplines - humanities, as well as social and natural science and should be considered in an interdisciplinary way. The best point of reference is the street; a place that brings together various people, whose collective acceptance affects the selection of a suitable outfit. Dress is dependent on many factors - financial status, the economic state, or the current trends in fashion. First of all, the dress is a carrier of numerous messages about an individual and it is one of the key elements of non-verbal communication. Both direct and indirect messages are associated with the selection of clothes: their purely functional use blends with messages carrying the information about social status, the occupation or belonging to a particular environment (Kuczyńska, 1983). Moreover an outfit carries a deeper, more personal message. When we consider dress as a person's second body (also belonging to this category are: architectural environment, arts, residential interiors, manners, views, and other elements specific to one's character), we should consider it in two categories: the first one - primordial, in which the garment serves a fully practical function, an the second one: human clothing treated as a metaphor, that deviates from the original assumptions (Kuczyńska, 1983). Therefore the language of fashion is difficult and often incomprehensible, even though it is used by almost everyone, and almost every day.

The complexity of the problem may create an impression that there is no one specific code, which should be followed in reading the message written in an outfit. However, one should keep in mind that in interpersonal relations the non-verbal message is incredibly important - and a significant part of it is dictated by fashion.

\section{REFERENCES}

Quotations used in the article derived from Polish texts were translated by the Author.

Bochnia, B., \& Bochnia, K. (2010). Ukryty program w komunikacji niewerbalnej na przykładzie wprowadzenia obowiązku noszenia jednolitego stroju w gimnazjach - niebezpieczeństwa i zagrożenie [Hidden programme in non-verbal communication on the example of the introduction of the obligation to wear uniforms in gymnasium - the dangers and threats]. In: K. Czerwiński, M. Fiedor, \& J. Kubiczek (Eds.). Komunikowanie społeczne w edukacji. Zagrożenia podmiotowe i psychospołeczne [Social communication in education. Subjective and psychosocial risks] (pp. 57-78). Toruń: Wydawnictwo Adam Marszałek.

Clothing of Arab women. (n.d.). Retrieved from http://www.islametinfo.fr/2012/04/30/bilan-apres-1-andapplication-de-la-loi-sur-le-niqab-en-france/voile-islamique-burqa-hijab-niqabtchador-burka-reuters/. Colors of mourning. (2013). Retrieved from http://www.eioba.pl/a/49z3/ kolory-zaloby.

Fisher-Mirkin, T. (1999). Mowa stroju [Dress code. Understanding the Hidden Meanings of Women's Clothes]. Warszawa: Wrocławska Drukarnia Naukowa PAN.

Gawlik, A. (2002). Wyrabianie wrażliwości estetycznej, prowadzenia notatek, estetyka miejsca, estetyka ubioru [Manufacturing aesthetic sensitivity, keep notes, the aesthetics of space, aesthetics clothing]. In: K. Misiołek (Ed.). Trójpodmiotowość w praktyce edukacyjnej szkoły zreformowanej [Trisubjectivity in educational practice of the reformed school] (pp. 197-200). Mysłowice: Górnośląska Wyższa Szkoła Pedagogiczna.

Gross, K. J., \& Stone, J. (2005). Kobieta sukcesu. Jak dobrać garderobę, by zdobyć i utrzymać posadę [Dress Smart Women]. Warszawa: MUZA SA. 
Hoffman, B. (2007). Styl ubierania się czynnikiem kształtowania tożsamości młodzieży [The dress factor in shaping youth identity]. Problemy Opiekuńczo-Wychowawcze, December 465, 28-32.

Happiness: it's not in the jeans. (2012). Retrieved from http://www.sciencedaily.com/releases/2012 /03/120308062537.htm.

König, R. (1979). Potęga i urok mody [The power and charm of fashion]. Warszawa: Wydawnictwo Artystyczne i Filmowe.

Kosowska, M. (2012). Ujednolicony strój szkolny a identyfikacja uczniów ze szkota na podstawie badań przeprowadzonych w wybranych szkołach małopolskich [Standardized school outfit and its influence on students' identification with school, study based on a research conducted in chosen schools in Lesser Poland]. Kraków: Akademia Ignatianum w Krakowie.

Kuczyńska, A. (1983). Wzory modne w życiu codziennym [Patterns of fashion in everyday life]. Warszawa: Wiedza Powszechna OMEGA.

Kuczyńska, T. (1977). Moda w rytmie epoki [Fashion in the rhythm of the era]. Warszawa: Wydawnictwo WARTA.

Leathers, D. G. (2007). Komunikacja niewerbalna. Zasady i zastosowania [Non-verbal communication. Principles and applications].Warszawa: Wydawnictwo Naukowe PWN.

Morreale, S. P., Spitzeberg, B. H., \& Barge, J. K. (2007). Komunikacja między ludźmi. Motywacja, wiedza $i$ umiejętności [Communication between people. Motivation, knowledge and skills]. Warszawa: Wydawnictwo Naukowe PWN.

Outfits of the ancient Romans. (n.d.). Retrieved from http:// www.imperiumromanum.edu.pl/ubior_rzymian.html. Rejakowa, B. (2010). Kulturowe aspekty jezzyka mody [Cultural aspects of the language of fashion]. Lublin: Wydawnictwo Uniwersytetu Marii Curie-Skłodowskiej.

Rock, Y. S. (2008). Zasady mody, czyli jak ubierać sie gustownie i z klasa [Fashion rules, how to dress tastefully and with class]. Warszawa: Wydawnictwo RM.

Sufa, B. (2008). Komunikacja niewerbalna. O porozumiewaniu się nauczycieli i uczniów w edukacji wczesnoszkolnej [Non-verbal communication. About communication teachers and students in early childhood education]. Kraków: Wydawnictwo Naukowe Akademii Pedagogicznej.

Tarczyński, D. (2006). Zrozumieć człowieka z wyglądu. Psychologia ubioru [Understanding human by the look. Psychology of clothing]. Białystok: Studio Astropsychologii.

Tinker v. Des Moines Independent Community School District. (1969). Retrieved from http://www.bc.edu/bc_ org/avp/cas/comm/free_speech/tinker.html.

Żygulski, Z. (1994). Strój jako forma symboliczna [Dress as a symbolic form]. In: A. Sieradzka, \& K. Turska (Eds.). Ubiory w Polsce. Materiaty III Sesji Klubu Kostiumologii i Tkaniny Artystycznej przy Oddziale Warszawskim Stowarzyszenia Historyków Sztuki Warszawa, październik 1992 [Dresses in Poland. Materials of the Third Session of the Costumology and Textile Art Club at the Warsaw the Department of the Association of Art Historians Warsaw, October 1992] (pp. 7-18). Warszawa: Wydawnictwo KOPIA. 